ARTICLE

\title{
Distribution and abundance of planktonic mollusks along a longitudinal gradient in the Southeastern Pacific off Chile
}

\author{
Distribución y abundancia de moluscos planctónicos en un gradiente longitudinal en el \\ Pacífico suroriental frente a Chile

\section{Bernardita Campos ${ }^{1 *}$ and Mauricio F. Landaeta $\left(\mathbb{D}^{2,3}\right.$}

${ }^{1}$ Escuela de Biología Marina, Facultad de Ciencias del Mar y de Recursos Naturales, Universidad de Valparaíso, Av. Borgoño 16344, Viña del Mar, Chile

${ }^{2}$ Centro de Observación Marina para Estudios de Riesgo del Ambiente Costero (COSTA-R), Universidad de Valparaíso, Av. Borgoño 16344, Viña del Mar, Chile

${ }^{3}$ Laboratorio de Ictioplancton (LABITI), Instituto de Biología, Facultad de Ciencias, Universidad de Valparaíso, Gran Bretaña 1091, Valparaíso, Chile. mauricio.landaeta@uv.cl

*Corresponding author: bernardita.campos@uv.cl

Resumen.- Los objetivos de esta investigación fueron estimar la abundancia de los principales grupos de moluscos planctónicos (larvas meroplanctónicas, gasterópodos holoplanctónicos y paralarvas de cefalópodos) y relacionarla con las propiedades fisicoquímicas del agua, a lo largo de un gradiente longitudinal entre Caldera en la costa continental de Chile y la ecorregión de Isla de Pascua (Isla de Rapa Nui e Isla Salas y Gómez), en el sureste del océano Pacífico. Se recolectaron muestras de plancton durante el Crucero CIMAR 21-Islas, en octubre y noviembre de 2015, en 33 estaciones oceanográficas con una red WP2 (180 $\mu$ m de abertura de malla) en lances verticales entre los $300 \mathrm{~m}$ de profundidad y la superficie del mar. Los moluscos se clasificaron, contaron y asignaron inicialmente a nivel de Clase, para su posterior identificación en niveles taxonómicos inferiores. Se obtuvieron moluscos planctónicos en todas las estaciones, con $92,7 \%$ de Gastropoda y 7,3\% de Bivalvia. La abundancia total de moluscos varió entre 55 y 4.922 individuos $100 \mathrm{~m}^{-3}$. Los gasterópodos Euthecosomata exhibieron la mayor ocurrencia en el área oceánica. No se obtuvieron paralarvas. Las diferencias en la composición de los moluscos planctónicos entre las zonas continental y oceánica se hicieron evidentes. Las larvas de bivalvos aumentaron su abundancia en aguas más cálidas, saladas y verticalmente mezcladas. Estos resultados son el primer registro de moluscos meroplanctónicos en aguas cercanas a las islas oceánicas chilenas. Los moluscos planctónicos presentan una variación espacial a escala de la cuenca del Pacífico Sur, relacionada con las condiciones hidrográficas y la estructura de la columna de agua.

Palabras clave: Meroplancton, holoplancton, ecología larval, Rapa Nui, islas oceánicas

Abstract.- The objectives of this research were to estimate the abundance of the main groups of planktonic mollusks (meroplanktonic larvae, holoplanktonic gastropods and cephalopod paralarvae), and relate these groups to the physical-chemical water properties along a longitudinal gradient between Caldera, on the coast of mainland Chile, and the Easter Island ecoregion (Rapa Nui Island and Salas y Gómez Island), in the Southeast Pacific Ocean. Plankton samples were collected over the course of the CIMAR 21-Islas Cruise, from October to November 2015, at 33 oceanographic stations via vertical hauls of a WP2 net (180- $\mu \mathrm{m}$ mesh size) from a maximum depth of $300 \mathrm{~m}$ to the sea surface. Mollusks were sorted, counted and initially assigned to Class rank, later being identified to lower taxonomic ranks. Planktonic mollusks were obtained at all stations, and were composed of $92.7 \%$ of Gastropoda and $7.3 \%$ of Bivalvia. The total abundance of mollusks varied between 55 and 4,922 individuals $100 \mathrm{~m}^{-3}$. Euthecosomate gastropods exhibited the highest occurrence within the oceanic area. Meanwhile, no paralarvae were captured. Differences in the composition of planktonic mollusks between the continental and oceanic zones were evident. Bivalve larvae increased their abundance in warmer, salty and vertically mixed waters. These results are the first record of meroplanktonic mollusks in waters near the Chilean oceanic islands, and suggest that planktonic mollusks display spatial variation at the scale of the South Pacific Basin, which could be related to the hydrographic conditions and the water column structure.

Key words: Meroplankton, holoplankton, larval ecology, Rapa Nui, oceanic islands 


\section{INTRODUCTION}

The Southeast Pacific region is characterized by a remarkable zonal gradient in both productivity and oceanographic conditions, from the highly productive and cold Humboldt Current ecosystem ( $>20 \mathrm{mg} \mathrm{m}^{-3} \mathrm{Chl}-a$ ) in the coastal zone to the oligotrophic/ultra-oligotrophic South Pacific central gyre $\left(<0.02 \mathrm{mg} \mathrm{m}^{-3} \mathrm{Chl}-a\right)$ (von Dassow \& Collado-Fabbri 2014, Meerhoff et al. 2018, Espinosa-Leal et al. 2021). These contrasting water mass properties across the zonal gradient may exert a strong influence on the distributional patterns of planktonic organisms (EspinosaLeal et al. 2021).

Planktonic mollusks play an important role in ocean trophic dynamics, by supporting secondary consumers which also inhabit the water column (Young \& Chia 1987), as well as in the biodiversity conservation, since their absence, presence or abundance in a given place can be used as indicators of environmental change (Shelton 2014). In addition, the geographic dispersion of adult populations may reflect characteristics of the life history of the species (Botsford et al. 2001, Shanks 2001, Young 2002, Trakhtenbrot et al. 2005).

Most benthic mollusks develop larvae in the water column as components of meroplankton, remaining as part of the planktonic community for a few hours up to months, or even years, depending on the species, environmental conditions and food availability (Scheltema 1986a, Pechenik 1987, Strathmann \& Strathmann 2007). Most of the mollusk larvae are either actaeplanic or teleplanic (Strathmann \& Strathmann 2007), the latter having the ability to be transported long distances (Shanks 1995). On the other hand, gastropod mollusks of the Order Pteropoda and the Superfamily Pterotracheoidea (=Heteropoda) develop their whole life cycle (larva, juvenile and adult) in the water column, forming part of the holoplankton. These gastropod groups are of particular importance because some species act as sensitive indicators of water masses (Chen \& Hillman 1970) and climate change (Hughes 2000), as well as playing an important role in the marine food web (Wall-Palmer et al. 2016). Cephalopod paralarvae and juveniles also form part of the planktonic mollusk community. Along with the other planktonic mollusks, they play a key role in marine food webs and have been considered potential indicators of environmental change (García-Guillén et al. 2018).

Planktonic mollusks from the Southeast Ocean off north-central Chile have mainly been the subject of general zooplankton studies or the identification of selected species (Fagetti 1958, 1968; Fagetti \& Fischer 1964, Palma et al. 1976, Prado 1983, Campos \& Ramorino 1984, Palma \& Rosales 1995, Vega et al. 1999, Poulin et al. 2002a, b; Romero \& Valdebenito 2002, Labrín et al. 2015, Torreblanca et al. 2016, Carrasco et al. 2019). However, the knowledge concerning the distribution and abundance of these groups is very scarce especially in oceanic areas. It was hypothesized that the main groups of planktonic mollusks would exhibit distribution and abundance patterns along the longitudinal gradient between Caldera and the Easter Island ecoregion (Rapa Nui Island and Salas y Gómez Island) according to the environmental conditions of the water column (i.e. groups related to coastal/productive waters, oceanic/oligotrophic waters, and around islands). The objectives of this study were to determine the abundance of main planktonic mollusks groups along a longitudinal transect between Caldera and the Easter Island ecoregion, and to relate their distribution with the physical-chemical characteristics of the water column.

\section{Materials AND METHODS}

This study was carried out along a longitudinal transect between Caldera $\left(\sim 27^{\circ} \mathrm{S}-70.1^{\circ} \mathrm{W}\right)$, on the continental coast, and the Easter Island ecoregion (Rapa Nui Island, $27^{\circ} \mathrm{S}-109^{\circ} 22^{\prime} \mathrm{W}$ and Salas y Gómez Island, $26^{\circ} 28^{\prime} \mathrm{S}$, $105^{\circ} 21^{\prime} \mathrm{W}$ ), Chile (Fig. 1), during the oceanographic cruise CIMAR 21-Islas, from October $13^{\text {th }}$ to November $4^{\text {th }}$ (austral spring) 2015, onboard the Chilean Navy research vessel AGS "Cabo de Hornos".

The continental coast of Caldera is influenced by Equatorial Subsurface Water and upwelling processes, generating a system high in nutrients. While towards Rapa Nui, the mesotrophic transition and oligotrophic zones are composed by Sub Antarctic Water and Subtropical Water, respectively, with lower nutrient concentrations compared to the coastal zone (González et al. 2020). The sea surface water temperatures and salinities, from the coast to the open ocean, range from 14.9 to $21.4^{\circ} \mathrm{C}$ and from 34.7 to 35.9 , respectively. A well-oxygenated surface layer $\left(>5 \mathrm{~mL} \mathrm{~L}^{-1}\right)$ has been recorded all along the latitudinal gradient, however its depth ranges from $\sim 35 \mathrm{~m}$, near the coast, to $\sim 215 \mathrm{~m}$, in the open ocean (Espinosa-Leal et al. 2021).

Mollusks were obtained from 60 plankton samples collected at 33 sampling stations (Fig. 1). At each station, samples were obtained by means of vertical tows of a WP2 net (180- $\mu \mathrm{m}$ mesh size), equipped with a TSK flowmeter, down to a maximum depth of $300 \mathrm{~m}$. The collected samples were preserved onboard with $96 \%$ ethanol. Once in the laboratory, this fixative was replaced with a solution of $96 \%$ ethanol with sodium glycerophosphate $(\mathrm{pH}>8.5)$. Each mollusk was manually removed from the sample under a Leica MZ8 stereo microscope and preserved in 96\% ethanol with sodium glycerophosphate. Every specimen was first assigned to one of the following Classes: Bivalvia or Gastropoda. Since gastropods have both holoplanktonic and meroplanktonic representatives, specimens of this Class were classified into three groups: 1 . Meroplanktonic larvae (from benthic species), 2. Order Pteropoda and 3. Superfamily Pterotracheoidea (=Heteropoda), based on Bouchet et al. (2017). 


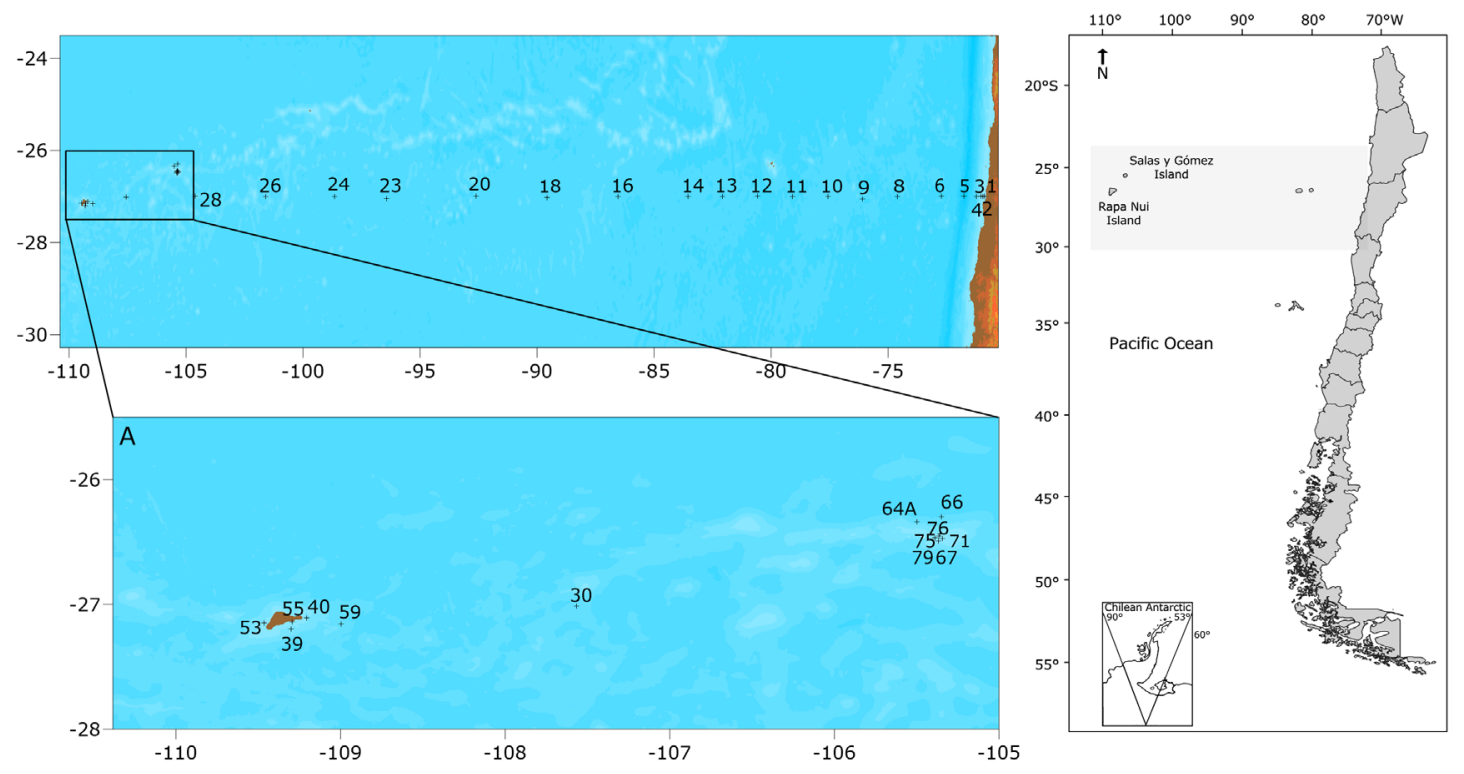

Figure 1. Location of the oceanographic stations of the CIMAR 21-Islas cruise, from October $13^{\text {th }}$ to November $4^{\text {th }}, 2015$. A) Rapa Nui (left) and Salas $y$ Gómez (right) island stations / Ubicación de las estaciones oceanográficas del crucero CIMAR 21-Islas, desde el 13 de octubre al 4 de noviembre, 2015. A) estaciones en las islas Rapa Nui (izquierda) y Salas y Gómez (derecha)

The abundance of mollusks was standardized in number of individuals $\cdot 100 \mathrm{~m}^{-3}$ (indiv. $100 \mathrm{~m}^{-3}$ ). Salinity, water temperature and dissolved oxygen data were recorded using a Seabird SB-19 CTD (conductivity/temperature/ depth profiler) at each sampling station. The environmental conditions were also characterized by vertical temperature, salinity and oxygen gradients, $\Delta \mathrm{V}=\mathrm{V}_{\text {sup }}-\mathrm{V}_{200 \mathrm{~m}}$, where $\mathrm{V}_{\text {sup }}$ is the surface value and $V_{200 m}$ is the value measured at 200 $\mathrm{m}$ depth for each of the corresponding variables. Prior to the correlation analyses between environmental variables and standardized mollusk abundances, the normality of the data was checked by means of the Shapiro-Wilk test. Since most of the analyzed variables did not fulfill the normality assumption $(P<0.05)$, the Spearman rank correlation was applied.

Adobe ${ }^{\circledR}$ Photoshop CS6 13.0 was used for editing the digital images of the mollusks. Global Mapper (Blue Marble Geographics) ${ }^{1}$ and Surfer ${ }^{\circledR} 10$ Golden Software, Llc; USA) software programs were used for graphics.

Comparisons were made between groups of stations, which were divided into oceanic waters $(\mathrm{O})$, Rapa Nui Island
(RN) and Salas y Gómez Island (SG). The standardized abundances of heteropods, pteropods and gastropod larvae were utilized for comparisons. A Principal Component Analysis (PCA) was applied to compare the mollusk composition among locations and was tested via a oneway PERMANOVA (Anderson 2001), using Bray-Curtis similarity index. All statistical analyses were carried out using Past 3.26 software (Hammer et.al 2001).

\section{RESULTS}

Planktonic mollusks were represented by larvae and juvenile Pteropoda Euthecosomata, Gymnosomata and Pterotracheoidea gastropods (holoplankton) as well as by larvae of benthic bivalves and gastropods (meroplankton), (Fig. 2). Cephalopod paralarvae were not captured.

The holoplanktonic Euthecosomata gastropods were represented by larvae and juveniles of the families Cavoliniidae (Cavolinia spp., Diacria spp.), Cliidae (Clio spp.), Creseidae (Creseis spp., Hyalocylis striata), Cuvierinidae (Cuvierina sp.) and Limacinidae (Limacina spp.). While, the Pseudothecosomata were represented by juveniles and adults of the families Desmopteridae (Desmopterus pacificus) and Peraclidae (Peracle spp.), and the Gymnosomata were only represented by larvae of the family Clionidae. The Pterotracheoidea were represented by larvae and juveniles of the family Atlantidae (Atlanta spp.).

${ }^{1}<$ https://www.bluemarblegeo.com/> 


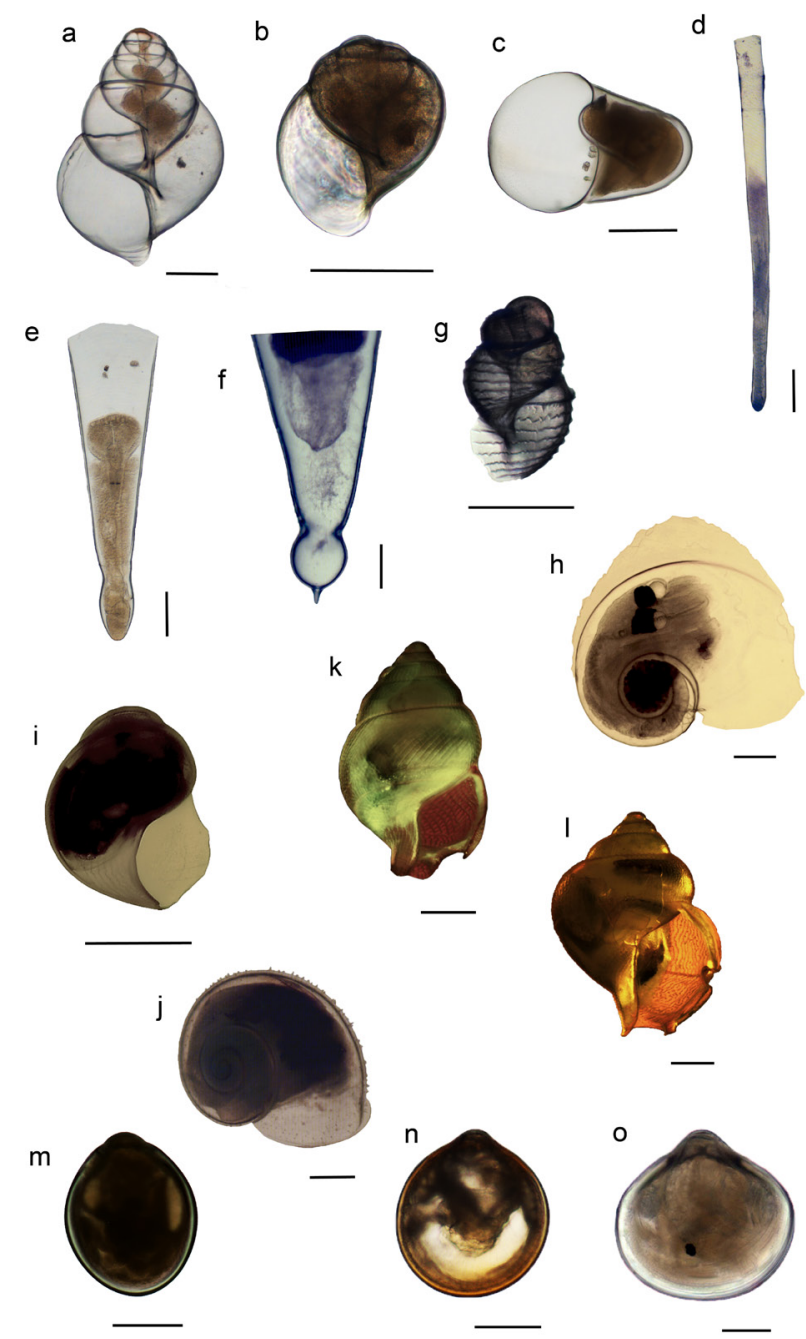

Figure 2. Selection of planktonic mollusks collected during the CIMAR-21 Cruise: a = Limacina bulimoides, b= Limacina sp., c= Heliconoides inflatus, $\mathrm{d}=$ Creseis acicula; e= Diacria quadridentata, $\mathrm{f}=$ Clio cuspidata; $\mathrm{g}=$ larva of Atlanta sp., $\mathrm{h}=$ adult Atlanta sp.; i-l= unidentified meroplanktonic gastropod larvae; $m=$ larva of Teredinidae bivalve, $n, 0=$ unidentified bivalve larvae. Scale bars: $a-l=200 \mu \mathrm{m} ; \mathrm{m}-0=\mathbf{1 0 0} \mu \mathrm{m} / \mathrm{Selección}$ de moluscos planctónicos recolectados durante el crucero Cimar-21: Limacina bulimoides, b= Limacina sp., c= Heliconoides inflatus, d= Creseis acicula; e= Diacria quadridentata, $\mathrm{f}=$ Clio cuspidata; $\mathrm{g}=$ larva de Atlanta sp., h= adulto de Atlanta sp.; i-l= larvas meroplanctónicas no identificadas de gasterópodos; m= larva de bivalvo Teredinidae, $\mathrm{n}, \mathrm{o}=$ larvas no identificadas de bivalvos. Barras de escala: $\mathrm{a}-\mathrm{I}=200 \mu \mathrm{m} ; \mathrm{m}-\mathrm{o}=100 \mu \mathrm{m}$

Over 40 morphotypes of gastropod larvae were collected. They were tentatively assigned to the families Neolepetopsidae, Seguenzidae, Trochidae, Cerithiidae, Turritellidae, Capulidae, Epitoniidae, Littorinidae, Naticidae, Triphoridae, Rissoidae, Eulimidae, Cymathiidae, Buccinidae, Columbellidae, Nassaridae, Muricidae, Mitridae, Siphonariidae, and to the order Nudibranchia. It was not possible to assign at least 15 morphotypes to their corresponding families. Nineteen morphotypes of bivalve larvae were collected. Fifteen morphotypes were tentatively assigned to the families Mytilidae, Arcidae, Gryphaeidae, Pectinidae, Anomiidae, Cardiidae, Teredinidae, Pholadidae, Lyonsiidae and Hiatellidae, whereas it was not possible to allocate 4 morphotypes to any families. Morphotype description of both benthic bivalve and gastropod larvae is still under way and will be published elsewhere.

\section{DisTRIBUTION AND ABUNDANCE}

Planktonic mollusks were collected at all the stations, adding to a total of 12,761 individuals.

The total standardized abundances of planktonic mollusks varied from 55 indiv. $100 \mathrm{~m}^{-3}$ (St. 24) in the oceanic area to 4,922 indiv. $100 \mathrm{~m}^{-3}$ (St. 4) over the shelf-break off Caldera (Fig. 3). Gastropods constituted $92.7 \%$ of the total mollusks collected, while bivalves only represented $7.3 \%$. The percentage of these two Classes varied among stations (Fig. 4), with gastropods dominating over $80 \%$ of 27 of the 33 sampled stations. The station (St.) 75, in waters bordering SG, was the only station with a greater abundance of bivalves (59\%) than gastropods. 

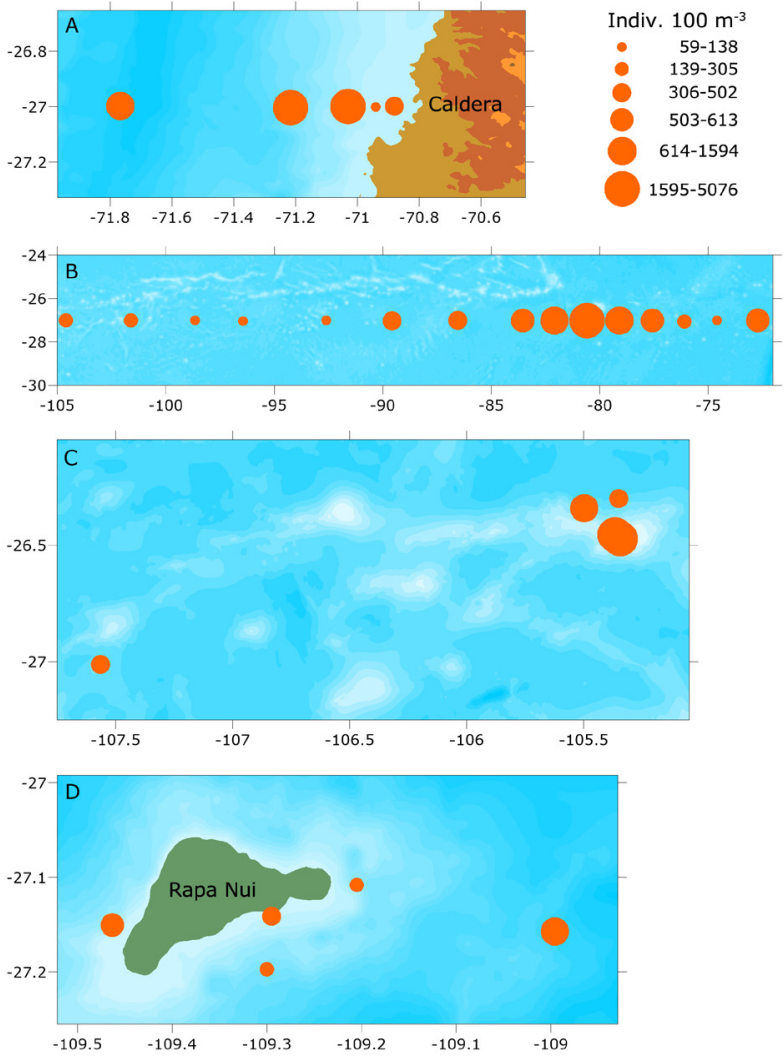

Figure 3. Standardized total abundance (indiv. $100 \mathrm{~m}^{-3}$ ) of planktonic mollusks collected during the CIMAR 21-Islas cruise, from October $13^{\text {th }}$ to November $4^{\text {th }}, 2015$. A) stations 1-5, B) stations 6-28, C) stations 30 and Salas y Gómez Island, D) stations Rapa Nui Island / Abundancia total estandarizada (indiv. $100 \mathrm{~m}^{-3}$ ) de moluscos planctónicos recolectados durante el crucero CIMAR 21-Islas, desde el 13 de octubre al 4 de noviembre, 2015. A) estaciones 1-5, B) estaciones 6-28, C) estaciones 30 e isla Salas y Gómez, D) estaciones Isla Rapa Nui
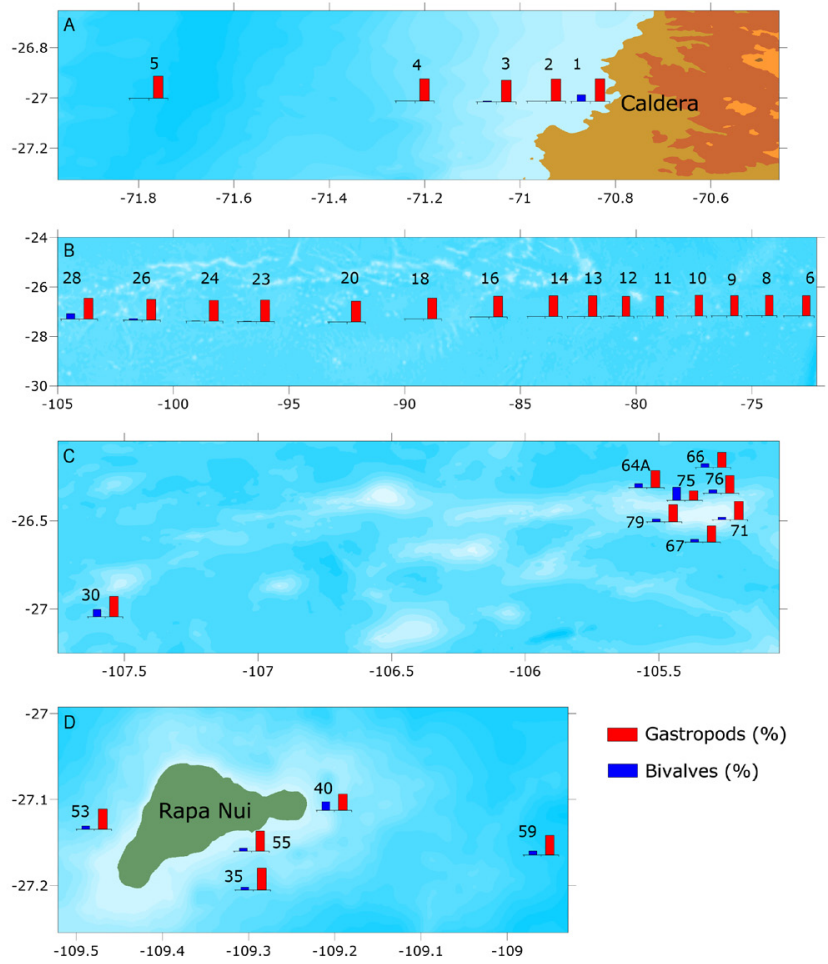

Figure 4. Percentage (\%) of gastropods (in red) and bivalves (in blue) collected during the CIMAR 21-Islas cruise, from October $13^{\text {th }}$ to November $4^{\text {th }}$, 2015. A) stations 1-5, B) stations 6-28, C) stations 30 and Salas y Gómez Island, D) stations Rapa Nui Island / Porcentaje de gasterópodos (en rojo) y bivalvos (en azul) recolectados durante el crucero CIMAR 21-Islas, desde el 13 de octubre al 4 de noviembre, 2015. A) estaciones 1-5, B) estaciones 6-28, C) estaciones 30 e isla Salas y Gómez, D) estaciones Isla Rapa Nui 

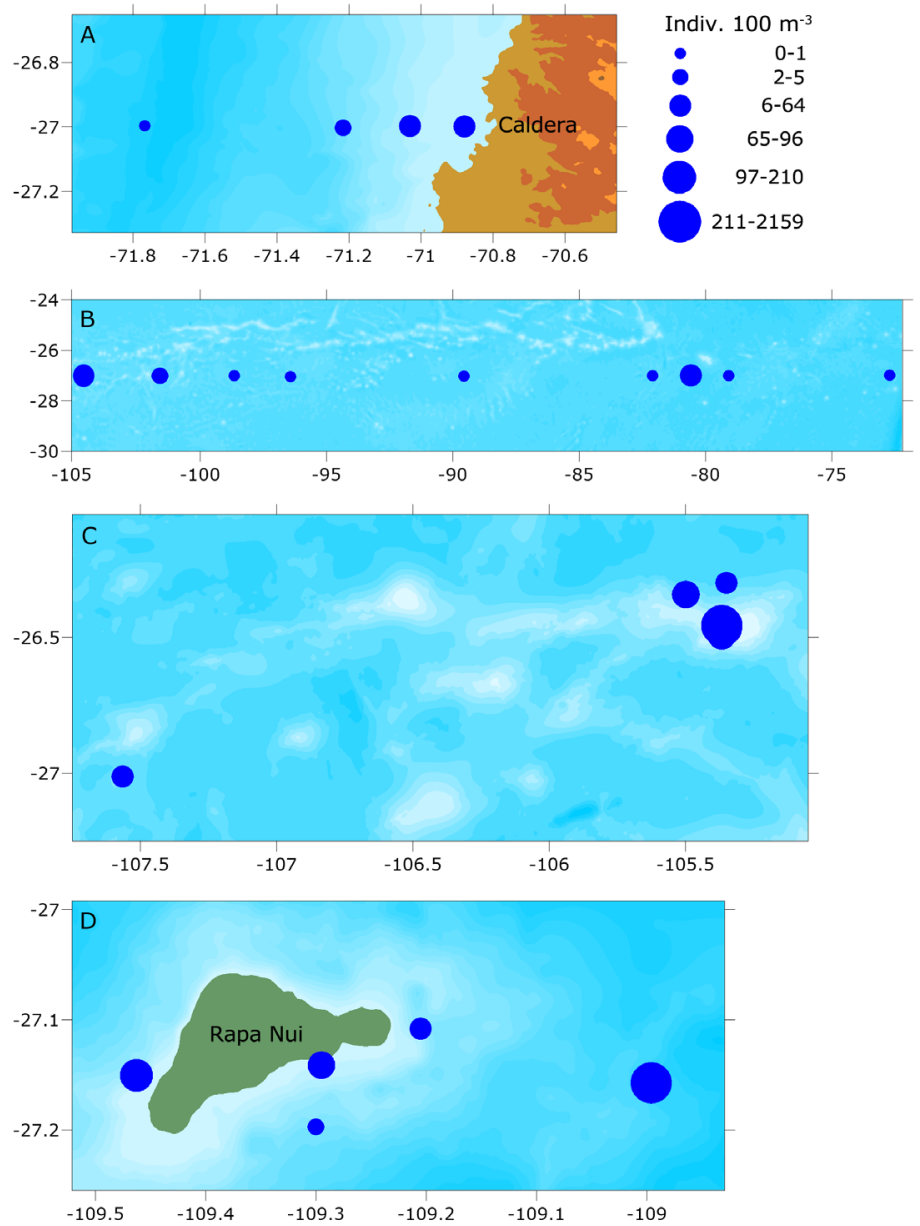

Figure 5. Standardized total abundance (indiv. $100 \mathrm{~m}^{-3}$ ) of bivalve larvae collected during the CIMAR 21-Islas cruise, from October $13^{\text {th }}$ to $\mathrm{November}$ $4^{\text {th }}$, 2015. A) stations 1-5, B) stations 6-28, C) stations 30 and Salas y Gómez Island, D) stations Rapa Nui Island / Abundancia total estandarizada (indiv. $100 \mathrm{~m}^{-3}$ ) de larvas de bivalvos recolectadas durante el crucero CIMAR 21-Islas, desde el 13 de octubre al 4 de noviembre, 2015. A) estaciones 1-5, B) estaciones 6-28, C) estaciones 30 e isla Salas y Gómez, D) estaciones Isla Rapa Nui

Abundance of bivalve larvae was highly variable along the longitudinal transect, ranging from 0 indiv. $100 \mathrm{~m}^{-3}$ (St. 2, 8, 9, 10, 14, 16 and 20) to 2,159 indiv. $100 \mathrm{~m}^{-3}$ (St. 75) (Fig. 5). Gastropods abundance also varied along the transect, spanning from 57 indiv. $100 \mathrm{~m}^{-3}$ (St. 24) to 5,037 indiv. $100 \mathrm{~m}^{-3}$ (St. 4) (Fig. 6).

Among the planktonic gastropods, the standardized abundance of heteropods varied between 1 indiv. 100 $\mathrm{m}^{-3}$ (St. 9) and 1,171 indiv. $100 \mathrm{~m}^{-3}$ (St. 71), with larger abundances around SG (Fig. 7). The standardized abundance of pteropods differed between 4 indiv. 100 $\mathrm{m}^{-3}$ (St. 8) and 2,601 indiv. $100 \mathrm{~m}^{-3}$ (St. 12). While the standardized abundance of meroplanktonic gastropod larvae ranged between 4 indiv. $100 \mathrm{~m}^{-3}$ (St. 24) and 2,831 indiv. $100 \mathrm{~m}^{-3}$ (St. 4), with larger abundances near the continental coast and around SG. Proportions of relative abundances of planktonic gastropods showed clear variations in dominance throughout the studied area. Larvae were dominant in coastal waters over the shelf and in the open ocean, while around Rapa Nui ratios were similar, though heteropods dominated the waters adjacent to Salas y Gómez Island (Fig. 7). 

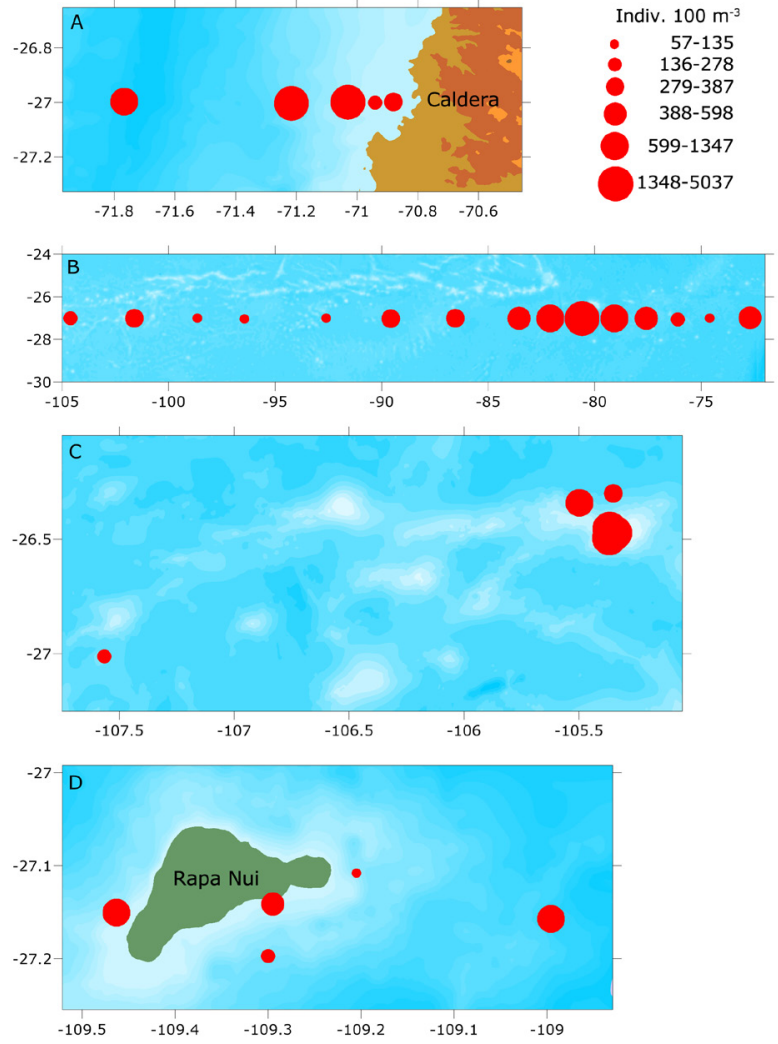

Figure 6. Standardized total abundance (indiv. $100 \mathrm{~m}^{-3}$ ) of planktonic gastropods collected during the CIMAR 21-Islas cruise, from October $13^{\text {th }}$ to November $4^{\text {th }}$, 2015. A) stations 1-5, B) stations 6-28, C) stations 30 and Salas y Gómez Island, D) stations Rapa Nui Island / Abundancia total estandarizada (indiv. $100 \mathrm{~m}^{-3}$ ) de gasterópodos planctónicos recolectados durante el crucero CIMAR 21-Islas, desde el 13 de octubre al 4 de noviembre, 2015. A) estaciones 1-5, B) estaciones 6-28, C) estaciones 30 e isla Salas y Gómez, D) estaciones Isla Rapa Nui
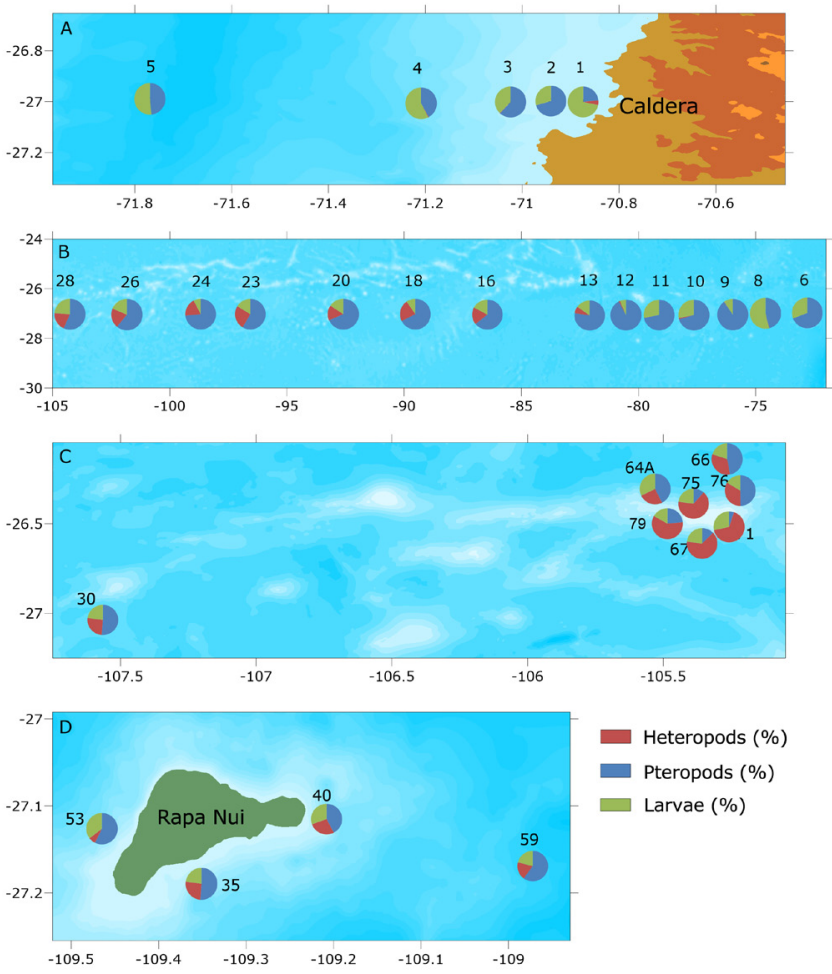

Figure 7. Percentage (\%) of Pterotracheoid heteropods (in red), pteropods (in blue) and meroplanktonic gastropod larvae (in green) collected during the CIMAR 21-Islas cruise, from October $13^{\text {th }}$ to November $4^{\text {th }}, 2015$. A) stations 1-5, B) stations 6-28, C) stations 30 and Salas y Gómez Island, D) stations Rapa Nui Island/ Porcentaje de heterópodos pterotracheoideos (en rojo), pterópodos (en azul) y larvas meroplanctónicas de gasterópodos (en verde), recolectados durante el crucero CIMAR 21-Islas, desde el 13 de octubre al 4 de noviembre, 2015. A) estaciones 1-5, B) estaciones 6-28, C) estaciones 30 e isla Sala y Gómez, D) estaciones Isla Rapa Nui 


\section{Multivariate ANALYSES}

The PCA was explained by three components. PC1 described $74.4 \%$ of the variance; PC2 explained $16.3 \%$, while PC3 illustrated only 9.3\% (Fig. 8). PC1 was explained by the variability in the abundances of both pteropods (loading factor $=0.798$ ) and gastropod larvae (loading factor $=0.601$ ). PC2 showed variability in the stations around $\mathrm{SG}$, and was positively correlated to larvae (loading factor $=0.661$ ) and heteropods (loading factor= 0.580) (Fig. 8). All the stations executed around Rapa Nui (RN) showed similar compositions, e.g., all sampled stations occurred in a similar multivariate space in the PCA(Fig. 8). One-way PERMANOVA detected significant differences among locations (pseudo- $F=3.24, P=0.005$ ). Post-hoc analysis showed that, at a major taxonomic group scale, composition and abundance of planktonic mollusks were different between SG and O (Bonferronicorrected $P=0.011), \mathrm{RN}$ and SG $(P=0.040)$, but not between $\mathrm{RN}$ and $\mathrm{O}(P=0.743)$. Therefore, the planktonic mollusk community along the longitudinal gradient was heterogeneous and differentially represented.

\section{RELATIONSHIP WITH ENVIRONMENTAL VARIABLES}

The standardized abundance of total mollusks did not significantly correlate with any of the environmental variables considered in this study $(P>0.151)$, nor did the gastropods $(P>0.177)$. However, the standardized abundance of bivalve larvae showed significant positive correlations with the mean water temperature ( $\mathrm{rs}=0.584$, $P<0.001)$, the sea surface temperature $(\mathrm{rs}=0.568, P$ $=0.001)$, the mean salinity ( $\mathrm{rs}=0.704, P<0.001)$ and the sea surface salinity ( $\mathrm{rs}=0.626, P<0.001$ ). On the other hand, the standardized abundance of bivalve larvae showed a negative correlation with the vertical temperature gradient ( $\mathrm{rs}=-0.541 ; P=0.002)$ and the vertical dissolved oxygen gradient ( $\mathrm{rs}=-0.542, P=0.002$ ). In summary, the standardized density of bivalve larvae increased in warmer, salty and vertically more mixed waters, while the hydrographic conditions and the water column structure did not have any significant effect on the abundance of total mollusks or gastropods.

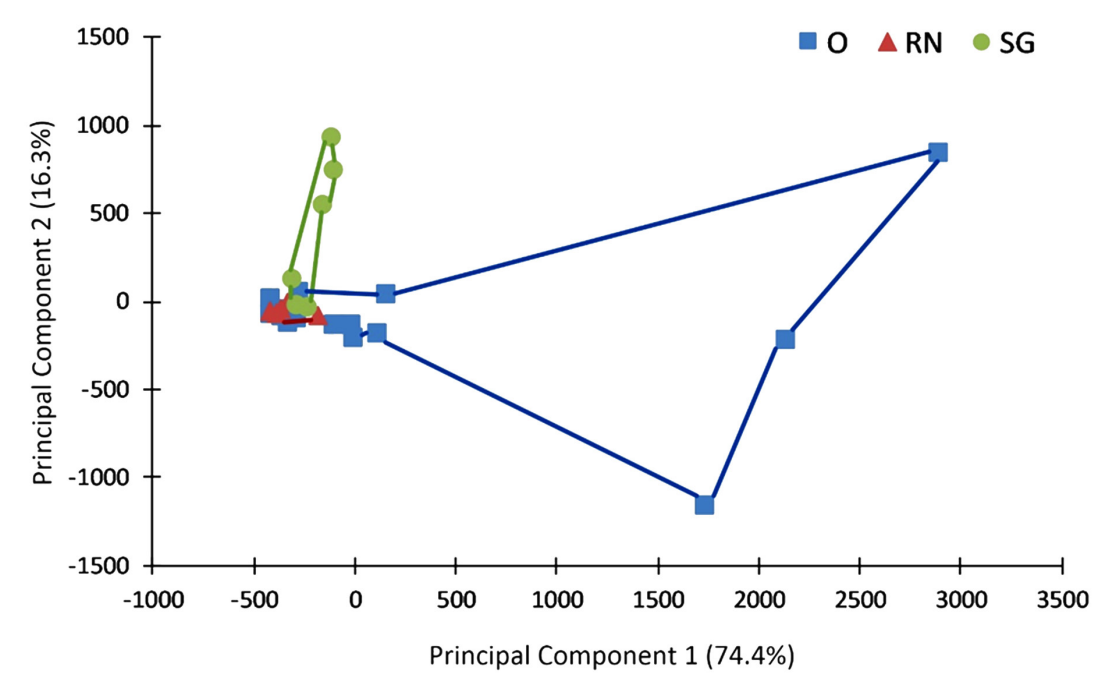

Figure 8. Principal Component Analysis (PCA) of composition and abundance of planktonic gastropods collected during austral spring 2015 in Southeast Pacific Ocean. O= oceanic, RN= Rapa Nui Island, SG= Salas y Gómez Island / Análisis de Componentes Principales (PCA) de la composición y abundancia de gasterópodos planctónicos recolectados durante la primavera austral 2015 en el océano Pacífico Sureste. O= oceánico, RN= isla Rapa Nui, SG= isla Salas y Gómez 


\section{Discussion}

\section{Distribution AND ABUNDANCE}

The spatial distributional patterns of planktonic mollusks clearly exhibited a longitudinal gradient along the South Pacific, from continental coastal waters to oligotrophic oceanic waters, and around the oceanic islands, indicating that both adult and larvae are able to live in different oceanographic conditions across the basin.

The high abundance of holoplanktonic mollusks close to the continental coast could be the result of El Niño Godzilla 2015-2016, where warmer waters reached the Chilean coast (Sánchez-Velasco et al. 2017). A similar environmental condition was found by Labrín et al. (2015) during a previous survey in almost the same study area. On the other hand, the distribution and abundance of pteropods and heteropods, especially in the open ocean and near the oceanic islands, showed a similar pattern to those reported by Labrín et al. (2015) in their study of pteropods.

Meroplanktonic larval distribution could be explained by oceanographic and biological processes occurring in coastal waters, the open ocean and around the oceanic islands. Larvae could be transported off the coast by mesoscale activity in the mesotrophic coastal transition zone (CTZ), which is principally characterized by northwest travelling eddies (Hormazabal et al. 2004, González et al. 2021). On the contrary, the wind-influenced coastal circulation would prevent larval transport out to the open ocean via coastal retention processes (Marín \& Moreno 2002, Aiken et al. 2011). The onshore-offshore temperature gradient could generate a physical barrier for more temperature-sensitive groups of planktonic mollusks, such as bivalve larvae which was the only group that showed a significant connection with the environmental conditions and structure of the water column.

Larvae found in the open ocean are more likely to be teleplanic, which have the ability to cross physicalchemical water barriers and survive even in oligotrophic waters (e.g., Teredinidae bivalve larvae; Scheltema \& Williams 1983). Scheltema (1986b) reported a $77.6 \%$ occurrence of teleplanic gastropod larvae in the surface waters of the Central Pacific Ocean, compared to the $47.1 \%$ of non-teleplanic larvae. Nevertheless, the occurrence of open ocean non-teleplanic gastropod and bivalve larvae, produced by demersal mollusks inhabiting seamounts and hydrothermal vents nearby the study area, cannot be discarded (see Yáñez et al. 2009, fig. 2 for seamounts location, and Fitzsimmons et al. 2014, fig. 1B for hydrothermal vents location). The absence of bivalve larvae in several oceanic stations could be explained by the short planktonic period ( $<4$ weeks) of many coastal species (Shanks 2009), whose larvae would have completed their planktonic stage in less time than that required to be transported off the coast.
The high variability in larval spatial abundances along the longitudinal gradient could be explained by the inherently patchy distribution, produced by the limited larval duration and episodic reproduction events exhibited by benthic mollusks (Shanks 2009), along with the water mass distribution. Although increases in larval abundances associated with higher temperatures have previously been recorded in closed coastal systems of Portugal and Tunisia (Chícharo \& Chícharo 2000, 2001; Ziadi et al. 2015), to date this pattern had not been registered in the oceanic waters of the Pacific Ocean. The greater abundance of larvae found in waters around Rapa Nui could be due to an island-mass effect, which could cause an increase in local productivity as described by von Dassow \& Collado-Fabbri (2014) and Meerhoff et al. (2018).

\section{MOLLUSK GROUPS}

Among the holoplanktonic mollusks, the occurrence of the pseudothecosomatous gastropod Desmopterus pacificus Essenberg, 1919 had previously been recorded in Chilean waters, at the beginning of the $20^{\text {th }}$ century, according to Labrín et al. (2015). Campos \& Ramorino (1984) recorded this species off Quintero $\left(32^{\circ} 45^{\prime} \mathrm{S}\right)$, between the surface and $200 \mathrm{~m}$ depth, in December 1982 and January 1983, amid a recorded ENSO (El Niño-Southern Oscillation) event (Ramorino 1984). Cruz (2012) collected D. papilio, in surface equatorial water, also during an ENSO event, in April 1997, and Quesquén et al. (2016) recorded this species throughout the ENSO event of 2013 to 2015 off the coasts of Callao and Pisco, in Peru. These results confirm that this species acts as a good indicator of warmer waters arriving to the Chilean coast from the tropical Pacific throughout ENSO periods, in this case, during the arrival of the El Niño Godzilla 2015-2016 (Sánchez-Velasco et al. 2017).

The pterotracheoid gastropod genus Atlanta, which is mainly distributed in warm waters (Moreno-Alcántara et al. 2014, 2017, 2020; Wall-Palmer et al. 2016, MorenoAlcántara 2019), and was collected at various stations during this cruise, had already been registered by Campos \& Ramorino (1984) (A. lesueurii) almost all year-round at a principal depth of $75 \mathrm{~m}$. Although Moreno-Alcántara et al. (2020) indicated the presence of 18 species of Atlanta in the Northeastern Pacific, Cruz (2012) only collected $A$. gaudichaudi, A. lesueurii and A. peronii, over the course of ENSO periods in Ecuador, while Quesquén et al. (2016) also recorded $A$. heliconoidea and A. turriculata in Peruvian waters. Of the pterotracheoids collected by Fagetti $(1958,1968)$ off the Chilean coast, only larvae of Pterotrachea sp. were captured with the WP2 net during this study. 
In relation to meroplanktonic gastropod and bivalve larvae, this is almost their first record from the coast off Caldera as well as the waters adjacent to the Chilean oceanic islands. The closest record of gastropod larvae to our study area is from the coastal location $30^{\circ} \mathrm{S}, 71^{\circ} 21^{\prime} \mathrm{W}$ (Romero \& Valdebenito 2002). Most of the families to which the larvae have been assigned so far in this study have previously been reported by Scheltema (1986b) for the Central Pacific islands, therefore representatives of these families seem to be common throughout the Pacific Ocean.

The absence of adult stages of some of the holoplanktonic gastropods in the samples as well as of paralarvae could have been largely due to a net effect. The WP2 net (180$200 \mu \mathrm{m}$ mesh size) is suitable for capturing larval stages of mollusks but would not be as efficient in catching adult stages of thecosomatous gastropods, over $1 \mathrm{~mm}$ or cephalopod paralarvae because of their greater capacity to evade the net. Labrín et al. (2015) collected adults of several species of thecosomatous gastropods, using an IKMT net (10 mm mesh size), and Carrasco et al. (2019) captured paralarvae in waters of Rapa Nui Island using nets of $300 \mu \mathrm{m}$ mesh size. In our research, mainly larval and juvenile stages of some of the genera collected by Labrín et al. (2015) were captured alongside a few adults of some of the species also recorded by these researchers.

The relative dominance of pteropods over the heteropods and meroplanktonic larvae in most stations should be interpreted with caution since the spatial distribution of the planktonic stages depends partly on, the developmental stage of the species, their capabilities to perform vertical migration and their kinetic behavior in response to oceanographic conditions (Young 1995, Kersten et al. 2019), as well as species-specific differences. These trends can also be affected by seasonality (e.g., the sampling period encompassed only the austral spring), mesoscale oceanographic conditions (e.g., shallow oxygen minimum zone near the continental shelf, ultra-oligotrophic conditions in the South Pacific Gyre, island-mass effect around oceanic islands) and interannual variability in environmental conditions (e.g., the presence of the strong El Niño Godzilla during late 2015-early 2016).

In summary, the pelagic mollusk community display spatial variation at the scale of the South Pacific Basin, which can be related to both the hydrographic conditions and the water column structure. A more intense spatial and temporal sampling of planktonic mollusks could help to provide advances in our knowledge of not only their probable origin, but also their contribution to the colonization and connectivity of the oceanic islands and seamounts within the Easter Island ecoregion as well as in the shallower coastal zones.

\section{ACKNOWLEDGMENTS}

We thank various people for their contribution to this research: Javier Vera-Duarte for collecting the plankton samples on board, Paula Daluz and Alejandro Castillo for their assistance in sorting the samples, Mario Cáceres for providing the graphical data from CTD, René Astudillo for preparing the graphics and Francesca Search for the English language revision. We also thank the crew of AGS "Cabo de Hornos", for their help on board. Finally, we thank the anonymous referees who helped to improve the manuscript with their valuable suggestions and comments. This research was funded by the Comité Oceanográfico Nacional de Chile (CONA, Grant C21F 15-04, CIMAR 21-Islas to B. Campos and M. Landaeta).

\section{LiTERATURE CITED}

Aiken CM, SA Navarrete \& JL Pelegri. 2011. Potential changes in larval dispersal and alongshore connectivity on the central Chilean coast due to an altered wind climate. Journal of Geophysical Research 116: G04026. <https:// doi.org/10.1029/2011JG001731, 2011G04026 1 of 14>

Anderson MI. 2001. A new method for non-parametric multivariate analysis of variance. Austral Ecology 26(1): 32-46.

Botsford LW, A Hastings \& SD Gaines. 2001. Dependence of sustainability on the configuration of marine reserves and larval dispersal distances. Ecology Letters 4(2): 144-150.

Bouchet P, J-P Rocroi, B Hausdorf, A Kaim, Y Kano, A Nützel, P Parkhaev, M Schrödl \& EE Strong. 2017. Revised classification, nomenclator and typification of gastropod and monoplacophoran families. Malacologia 61(1-2): 1-526.

Campos B \& L Ramorino. 1984. Moluscos. In: Ramorino L (ed). Vigilancia de variaciones climatológicas y biooceanográficas en la zona de Quintero, Chile ( $\left.32^{\circ} 45^{\prime} \mathrm{S}\right)$, en relación al Fenómeno "El Niño". Informe final, Instituto de Oceanología, Universidad de Valparaíso, Valparaíso, $473 \mathrm{pp}$.

Carrasco SA, E Meerhoff, B Yannicelli \& CM Ibáñez. 2019. First records and descriptions of early life stages of cephalopods from Rapa Nui (Easter Island) and the nearby Apolo seamount. Pacific Science 73(1): 163-175.

Chen C \& NS Hillman. 1970. Shell-bearing pteropods as indicators of water masses off Cape Hatteras, North Carolina. Bulletin of Marine Science 20(2): 350-367.

Chícharo LMZ \& MA Chícharo. 2000. Short-term fluctuations in bivalve larvae compared with some environmental factors in a coastal lagoon (South Portugal). Scientia Marina 64(4): 413-420.

Chícharo L \& MA Chícharo. 2001. Effects of environmental conditions on planktonic abundances and growth rates of the bivalve mollusc Ruditapes decussatus in a Portuguese coastal lagoon. Fisheries Research 53(3): 235-250.

Cruz M. 2012. Preferencia y rangos de tolerancia a la temperatura y salinidad de los Pterópodos y Heterópodos frente a la costa ecuatoriana. Acta Oceanográfica del Pacífico 17(1): 93-124. 
Espinosa-Leal L, R Escribano, R Riquelme-Bugueño \& A Corredor-Acosta. 2021. Distribution and biodiversity patterns of hyperiid amphipods across the coastal-offshore gradient of the sub-tropical Southeast Pacific. Marine Biodiversity 51(1): 13. <https://doi.org/10.1007/s12526020-01152-x>

Fagetti E. 1958. Dos especies de moluscos planctónicos (Heteropoda) encontrados frente a la costa de Chile. Revista de Biología Marina 8(1,2 y 3): 143-147.

Fagetti E. 1968. Nueva localidad para dos especies de moluscos heterópodos Pterotrachea scutata Gegenbauer 1885 y Cardiapoda richardi Vayssiére 1904, encontradas por primera vez en el Pacífico sur-oriental frente a Chile. Revista de Biología Marina 13(3): 287-291.

Fagetti E \& W Fischer. 1964. Resultados cuantitativos del zooplancton colectado frente a la costa chilena por la Expedición "Marchile I". Revista de Biología Marina 11(4): 137-193.

Fitzsimmons JN, EA Boyleb \& WJ Jenkinsc. 2014. Distal transport of dissolved hydrothermal iron in the deep South Pacific Ocean. Proceedings of the National Academy of Sciences of the United States of America 111(47): 1665416661.

García-Guillén RM, R De Silva-Dávila \& R AvendañoIbarra. 2018. Seasonal changes in paralarval cephalopod communities on the southwest coast of Baja California Sur (spring and autumn 2003). Ciencias Marinas 44(2): 107-123.

González CE, J Medellín-Mora \& R Escribano. 2020. Environmental gradients and spatial patterns of Calanoid copepods in the Southeast Pacific. Frontiers in Ecology and Evolution 8: 554409. <https://doi.org/10.3389/ fevo.2020.554409>

Hammer Ø, DAT Harper \& PD Ryan. 2001. PAST: Paleontological statistics software package for education and data analysis. Palaeontologia Electronica 4(1): 1-9 $<\mathrm{http}$ ://palaeo-electronica.org/2001_1/past/issue1_01.htm>

Hormazabal S, G Shaffer \& O Leth. 2004. Coastal transition zone off Chile. Journal of Geophysical Research: Oceans 109(C1): 1-13

Hughes L. 2000. Biological consequences of global warming: is the signal already apparent? Trends in Ecology and Evolution 15(2): 56-61.

Kersten O, EW Vetter, MJ Jungbluth, CR Smith \& E Goetze. 2019. Larval assemblages over the abyssal plain in the Pacific are highly diverse and spatially patchy. PeerJ 7:e7691. <http://doi.org/10.7717/peerj.7691>

Labrín M, G Guzmán \& W Sielfeld. 2015. Pterópodos thecosomados en el Pacífico suroriental frente a Caldera, Chile (Mollusca Opisthobranchiata: Euthecostomata y Pseudothecostomata). Latin American Journal of Aquatic Research 43(1): 71-79.

Marín V \& C Moreno. 2002. Wind driven circulation and larval dispersal. A review of its consequences in coastal benthic recruitment. In: Castilla JC \& JL Largier (eds). The oceanography and ecology of the nearshore and bays in Chile. Proceedings of the International Symposium on Linkages and Dynamics of Coastal Systems: Open Coasts and Embayments, pp. 47-63. Ediciones Universidad Católica de Chile, Santiago.
Meerhoff E, M Ramos, B Yannicelli, L Bravo, D Zambra \& C Varela. 2018. Meroplankton distribution in South Pacific islands, implications for larval connectivity. Journal of Plankton Research 40(1): 77-90.

Moreno-Alcántara M. 2019. Atlantidae (Pterotracheoidea) of the Northeast Pacific. Zoosymposia 13(1): 139-146.

Moreno-Alcántara M, G Aceves-Medina, O AnguloCampillo \& JP Murad-Serrano. 2014. Holoplanktonic mollusks (Gastropoda: Pterotracheoidea, Thecosomata and Gymnosomata) from the southern Mexican Pacific. Journal of Molluscan Studies 80(2): 131-138.

Moreno-Alcántara M, A Giraldo \& G Aceves-Medina. 2017. Heteropods (Gastropoda: Pterotracheoidea) identified along a coastal-oceanic transect in the Colombian Pacific. Boletin de Investigaciones Marinas y Costeras 46(2): 175-181.

Moreno-Alcántara M, D Delgado-Hofmann \& G AcevesMedina. 2020. Diversity of Atlantidae mollusks (Gastropoda: Pterotracheoidea) from the southern region of the California current off Baja California peninsula, Mexico. Marine Biodiversity 50(2): 1-9. <https://doi. org/10.1007/s12526-020-01059-7>

Palma S \& S Rosales. 1995. Composición, distribución y abundancia estacional del macroplancton de la bahía de Valparaíso. Investigaciones Marinas, Valparaíso 23: 49-66.

Palma S, J Meruane \& A Mujica. 1976. Observaciones sobre el meroplancton del archipiélago de Juan Fernández. Enero, 1974. Ciencia y Tecnología del Mar, Valparaíso 2: 117-126.

Pechenik JA. 1987. Environmental influences on larval survival and development. In: Giese AC, JS Pearse \& VB Pearse (eds). Reproduction of marine invertebrates 9: 551608. Blackwell Scientific Publication and The Boxwood Press, Palo Alto and Pacific Grove.

Poulin E, A Palma, G Leiva, E Hernández, P Martínez, S Navarrete \& JC Castilla. 2002a. Temporal and spatial variation in the distribution of epineustonic competent larvae of Concholepas concholepas along the central coast of Chile. Marine Ecology Progress Series 229: 95-104.

Poulin E, A Palma, G Leiva, D Narváez, R Pacheco, S Navarrete \& JC Castilla. 2002b. Avoiding offshore transport of competent larvae during upwelling events: the case of the gastropod Concholepas concholepas in central Chile. Limnology and Oceanography 47(4): 1248-1255.

Prado R. 1983. Nota sobre cefalópodos decápodos colectados alrededor de las Islas de Pascua y Sala y Gómez. Boletín de la Sociedad de Biología de Concepción 54: 159-162.

Quesquén R, P Ayón \& L Vásquez. 2016. Moluscos holoplanctónicos (Mollusca: Heteropoda y Thecosomata) como indicadores de la variabilidad oceanográfica y del evento El Niño frente a Callao y Pisco, del 2013 al 2015. Boletín Trimestral Oceanográfico IMARPE 2(1): 12-16.

Ramorino L. 1984. Vigilancia de variaciones climatológicas y bio-oceanográficas en la zona de Quintero, Chile $\left(32^{\circ} 45^{\prime} \mathrm{S}\right)$ en relación al fenómeno "El Niño". Informe final, Universidad de Valparaíso, Valparaíso, pp. 73-83.

Romero MS \& E Valdebenito. 2002. Larvas veliger de gastrópodos prosobranchia provenientes de Punta de Lobos, IV Región, Chile. Revista Chilena de Historia Natural 75(3): 491-514. 
Sánchez-Velasco L, E Beier, VM Godínez, ED Barton, E Santamaría-del-Angel, SPA Jiménez-Rosemberg \& SG Marinone. 2017. Hydrographic and fish larvae distribution during the "Godzilla El Niño 2015-2016" in the northern end of the shallow oxygen minimum zone of the Eastern Tropical Pacific Ocean. Journal of Geophysical Research: Oceans 122(3): 2156-2170.

Scheltema RS. 1986a. On dispersal and planktonic larvae of marine invertebrates: an eclectic overview and summary of problems. Bulletin of Marine Science 39(2): 290-322.

Scheltema RS. 1986b. Long-distance dispersal by planktonic larvae of shoal-water benthic invertebrates among central Pacific islands. Bulletin of Marine Sciences 39(2): 241-256.

Scheltema RS \& IP Williams. 1983. Long-distance dispersal of planktonic larvae and the biogeography and evolution of some Polynesian and western Pacific mollusks. Bulletin of Marine Science 33(3): 545-565.

Shanks AL. 1995. Mechanisms of cross-shelf dispersal of larval invertebrates and fish. In: McEdward L (ed). Ecology of marine invertebrate larvae, pp. 323-367. CRC Press, Boca Raton.

Shanks AL. 2001. An identification guide to the larval marine invertebrates of the Pacific Northwest, 314 pp. Oregon State University Press, Corvallis.

Shanks AL. 2009. Pelagic larval duration and dispersal distance revisited. The Biological Bulletin 216(3): 373-385.

Shelton C. 2014. Climate change adaptation in fisheries and aquaculture. Compilation of initial examples. FAO Fisheries \& Aquaculture Circular 1088: 1-34.

Strathmann MF \& RR Strathmann. 2007. An extraordinarily long larval duration of 4.5 years from hatching to metamorphosis for teleplanic veligers of Fusitriton oregonensis. The Biological Bulletin 213(2): 152-159.

Torreblanca ML, I Pérez-Santos, B San Martín, E Varas, R Zilleruelo, R Riquelme-Bugueño \& AT Palma. 2016. Seasonal dynamics of zooplankton in a northern Chile bay exposed to upwelling conditions. Revista de Biología Marina y Oceanografía 51(2): 273-291.

Trakhtenbrot A, R Nathan, G Perry \& DM Richardson. 2005. The importance of long-distance dispersal in biodiversity conservation. Diversity and Distributions 11(2): 173-181.
Vega MA, FJ Rocha, A Guerra, C Osorio \& V Marín. 1999. Estudio preliminar de paralarvas de cefalópodos recolectados frente a la península de Mejillones (Antofagasta, Chile). Amici Molluscarum (SMCh) 7: 25-31.

von Dassow P \& S Collado-Fabbri. 2014. Biological oceanography, biogeochemical cycles, and pelagic ecosystem functioning of the east-central South Pacific Gyre: focus on Easter Island and Salas y Gómez Island. Latin American Journal of Aquatic Research 42(4): 703742.

Wall-Palmer D, CW Smart, R Kirby, MB Hart, KTCA Peijnenburg \& AW Janssen. 2016. A review of the ecology, paleontology and distribution of atlantid heteropods (Caenogastropoda: Pterotracheoidea: Atlantidae). Journal of Molluscan Studies 82(2): 221-234.

Yáñez E, C Silva, R Vega, F Espíndola, L Álvarez, N Silva, S Palma, S Salinas, E Menschel, V Häussermann, D Soto \& N Ramírez. 2009. Seamounts in the southeastern Pacific Ocean and biodiversity on Juan Fernandez seamounts, Chile. Latin American Journal of Aquatic Research 37(3): 555-570.

Young CM. 1995. Behavior and locomotion during the dispersal phase of larval life. In: McEdward L (ed). Ecology of marine invertebrate larvae, pp. 249-277. CRC Press, Boca Raton.

Young CM. 2002. A brief history and some fundamentals. In: Young CM (ed). Atlas of marine invertebrate larvae, pp. 1-19. Academic Press, San Diego.

Young CM \& F-S Chia. 1987. Abundance and distribution of pelagic larvae as influenced by predation, behavior, and hydrographic factors. In: Giese A, J Pearse \& V Pearse (eds). Reproduction of marine invertebrates 9: 385-463. Blackwell Scientific Publications and The Boxwood Press, Palo Alto and Pacific Grove.

Ziadi B, A Dhib, S Turki \& L Aleya. 2015. Bivalve and barnacle larvae distribution driven by water temperature in a Mediterranean lagoon. Environmental Science and Pollution Research 22(9): 7002-7011. 